\title{
RECYCLING OF ORGANIC WASTES THROUGH THE VERMICOMPOSTING PROCESS OF COW DUNG AND CROP RESIDUES
}

\author{
MD. AMINUL ISLAM ${ }^{*}$, MD. SHARIF UDDIN TALUKDER ${ }^{1}$, MD. SHAFIQUL ISLAM $^{1}$, \\ MOHAMMED SADID HOSSIAN ${ }^{2}$ AND M.G. MOSTOFA ${ }^{3}$
}

Palli Daridro Bimochon Foundation, Mirpur 2, Dhaka-1216

\begin{abstract}
Fertilizer is considered to be one of the main inputs for increasing crop yields. Chemical fertilizer industries are highly energy intensive and have a fundamental dependence on natural gas supply. On the other hand, organic fertilizers are the safer sources of plant nutrients without any detrimental effect on crops and soil. In the era of technological innovation, the farmers are interested to grow HYV rice and other diversified crops to support huge population of Bangladesh. So various harmful chemicals were used which degraded the health of the soil. Vermicompost is an excellent, nutrient-rich organic fertilizer and soil conditioner. It can bring back the fertility of the soil. Vermicomposting with earthworms has been recognized as a composting technique that transforms complex organic substances into stabilized, humus-like product. The application of vermicompost to the soil is considered as a good management practice in any agricultural production system because of the stimulation of soil microbial growth and activity and mineralization of plant nutrients and increased soil fertility and quality. This research focuses on producing nutrient-rich organic fertilizer by vermicomposting process from biomass. An experimental setup was carried out in Doulatpur, Kushtia targeting 10 tons output per month. Cow dung and crop residues were collected and followed vermicomposting method. Three cycles were maintained in the experiments i.e. 120 days per cycle-360 days in total and counted the vermi population for each consecutive cycle. The output fertilizer was analyzed in the laboratory and it was observed that the component ratios were suitable for agricultural lands. This fertilizer can also be used as a remedy for the barren lands. For the sustainable crop production and net improvement of soil productivity, vermicomposing is an excellent process to produce organic fertilizer from biomass.
\end{abstract}

Keywords: Recycling, Earthworms, Vermicomposting, Waste management, Cow dung, Crop residues

\section{INTRODUCTION}

There is a variety of wastes which are generated through different agricultural and other activities in our daily life including crop residues in the form of straw, stover, husk, biomass of uncultivated plant species and weeds, forest biomass; animal wastes and by-

products like dung, urine, bones, fish processing wastes and human habitation wastes like garbage, sewage and sludge etc. Crop residues are abundantly generated in large quantities during crop cultivation. After harvesting the economic part(s) of the plants,

* Corresponding author:<aminulbd62@gmail.com>.

1 Palli Daridro Bimochon Foundation, Mirpur 2, Dhaka-1216.

2 Department of Soil, Water and Environment, University of Dhaka, Dhaka-1000.

3 Institute of Energy, University of Dhaka, Dhaka-1000. 
rests are considered as wastes and are dumped on field side in a mound. These accumulated wastes left on the field side causes major unpleasant odors and create disposal problems. They also create environmental problems like occupying a vast area, spreading foul odors and forming breeding home for most of the pathogenic microorganism and mosquito vector. Furthermore, they are often the source of contamination of groundwater. Another organic manure, Cow dung is an important source of nitrogen for crop production. It helps farmers to reduce inputs of commercial fertilizer, thereby increasing the profit of the farmer. Nutrients contained in organic manures are released more slowly and are stored for a longer time in the soil, thereby ensuring a long residual effect, thus supporting better root development, higher crop yields. However, most of these potentially nutritious wastes are recyclable organic matter and good source of organic carbon. These huge inexpensive nutrient source or otherwise unused organic waste can be utilized for recycling as valuable resources. Considering deficiency of plant nutrients in crop field, higher cost of synthetic fertilizers and poor efficiency of chemical fertilizer, the organic wastes recycling for plant nutrient supply is becoming more essential for replenishment of plant nutrients, sustaining soil health, reducing the pollution problem and creating employment opportunities, which is now being increasingly recognized as a strategy for sustainable crop production. The organic wastes generally showed no adverse effects on crop yield, soil fertility or biological activity, but rather a stimulation of some properties, by reducing dependence on offfarm inputs and creating more balanced nutrient and energy flows and ecosystem resilience is strengthened, food security is increased and additional income is generated (Peterson et al. 2003). Tandon (1995) stated that a sizeable proportion of nutrient needs of agriculture, horticulture, forest and aquaculture can be met through appropriate recycling of a number of wastes and byproducts. With the changing scenario, recent years have witnessed a renewed interest for sustainable crop production by revitalizing and restoring the soil fertility and reviving the microbial activity to make the soil lively and healthy.

\section{A. Chemical vs. Organic fertilizer}

Bangladesh has a large agrarian base with $76 \%$ of the total population living in the rural areas and $90 \%$ of the rural people are directly related to agriculture. Fertilizer is considered to be one of the main inputs for increasing crop yields and farm profit. The conventional system uses chemical fertilizers mainly urea, superphosphate and potash. However, the continuous use of chemical fertilizer:

: deteriorates the soil structure (Shimbo 2001).

: accumulates heavy metals in plant tissues compromising nutrition value and edible quality of crops (Toor et al. 2006).

: reduces the protein content of crops (Karungi 2006).

: excess potassium decreases Vitamin C, carotene content and antioxidant compounds in vegetables (Smil 2001).

: crops grown on chemically overfertilized soils are also more prone to attacks by insects and disease (Peyvast et al. 2007). 
: the negative effects of chemical fertilizer on soil and environment limit their uses in sustainable agricultural (Clarks et al. 1998).

: $\quad$ soil $\mathrm{pH}$ becomes higher with organic agriculture (Olfati et al. 2009)

: the total microbial population in soil increases under organic agriculture (Blatt 1991).

Organic fertilizers such as cow dung, spent mushroom compost and municipal solid wastes compost (MSWC) are often identified as suitable local organic fertilizers. However, slow rate of mineralization of these organic fertilizers causes an apparent deficiency of adequate plant available $\mathrm{N}$ supply resulting in lower crop yields compared to chemical fertilizer.

\section{B. Vermicomposting}

Vermicompost has all the advantage of organic fertilizers plus readily available plant nutrients include macro and micronutrients. It is the ideal fertilizer for crop plants. Vermicomposting is a bio-oxidative process in which earthworms interact intensively with microorganisms and other fauna within the decomposer community, accelerating the stabilization of organic matter and modifying its physical and biochemical properties. The action of the earthworms in this process is physical or mechanical. Physical participation in degrading organic substrates results in fragmentation, thereby increasing the surface area of action, turnover and aeration. On the other hand, biochemical changes in the degradation of organic matter are carried out by microorganisms through enzymatic digestion, enrichment by nitrogen excrement and transport of inorganic and organic materials (Yadav et al. 2013). The benefits of vermicomposting in the recycling of organic wastes, animal wastes, crop residues, industrial waste etc. are reported at laboratory scale, but there is a paucity of data on the applicability of vermicomposting technology under natural environmental conditions. In this study, we particularly focus on vermicomposting of cow dung and crop residues under field conditions.

\section{METHODOLOGY}

The population of the earthworm is selfcontrolled and limited by available food, space and environmental conditions. Under perfect conditions, worm populations can be expected to double every 60 to 90 days (web1). A mature breeder has high reproduction rate and produces a cocoon every 7 to 10 days. It is possible to hatch a large number of earthworms out of an initial small setup. Comparing these net advantages we choose the vermicomposting method to process animal waste.

\section{Experimental Setup}

A small vermicompost plant was built in a village: Mohishkundi, Thana: Doulatpur, District: Kushtia. The plant had 16 beds to process around $10 \mathrm{MT}$ of cow dung and crop residue like stalks and stubble (stems), leaves, and seedpods etc (Fig. 1).

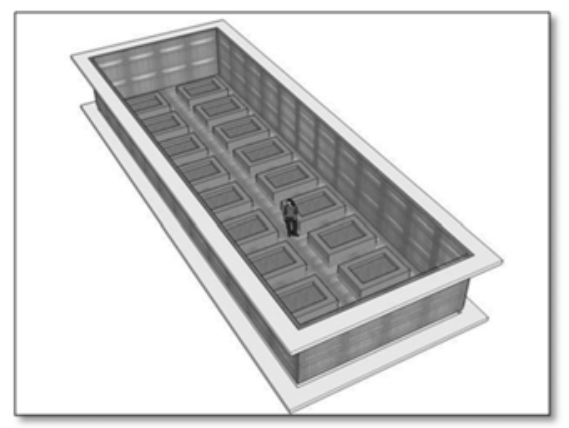

Fig. 1.Top 3D view of the compost plant. 
The beds were 5 feet in length, 2 feet in height, and 3 feet in width (with R.C.C slab) where each bed can process approximately $500 \mathrm{~kg}$ of wet cow dung and crop residues and produce $150-200 \mathrm{~kg}$ of output fertilizer per month (Fig. 2). The feeding layer was kept less than 1 foot. The entire structure and beds were surrounded by boundary walls to protect the facilities from birds, and other predator insects $\&$ animals. animal waste and crop residue on an average price of $1 \mathrm{BDT} / \mathrm{kg}$. Total raw material collection cost was around $1.5 \mathrm{BDT} / \mathrm{kg}$ where additional $0.5 \mathrm{BDT} / \mathrm{kg}$ is spent on packaging and transportation.

\section{Moisture control}

Worms breathe through their skins and if their skin dries out, they die. The bedding should absorb and retain water fairly enough

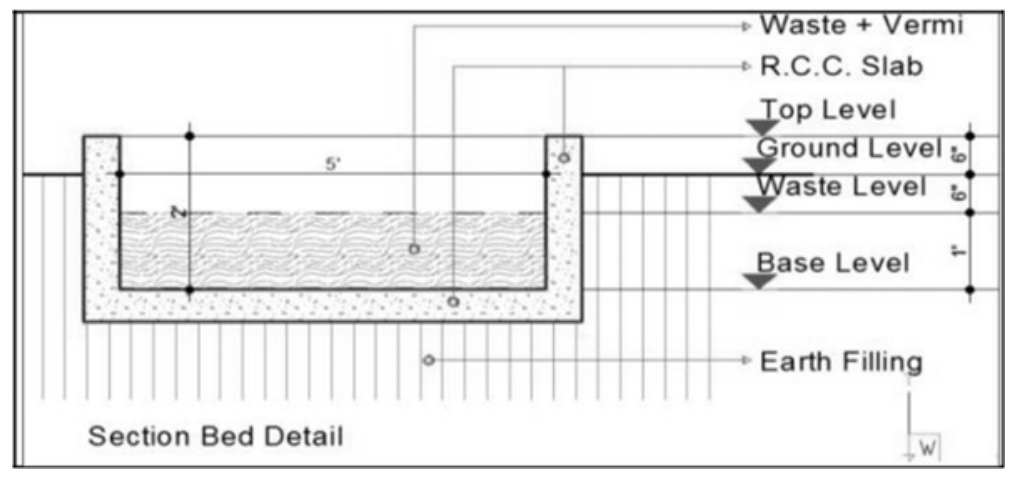

Fig. 2. Cross sectional view of worm beds.

\section{Temperature control}

The ideal temperature range for vermicomposting is $15^{\circ} \mathrm{C}$ to $25^{\circ} \mathrm{C}$. In Kushtia, the average annual temperature is $26^{\circ} \mathrm{C}$. May is the warmest month of the year and the temperature in May averages $30^{\circ} \mathrm{C}$. January has the lowest average temperature of the year. It is $18.5^{\circ} \mathrm{C}$ (web-2). We made a tin shaded structure above the beds and constructed the beds 1.5 feet beneath the surface to use the ground temperature.

\section{Raw material collection}

To ensure enough feed supply, the project team announced among the villagers to store up cow dung and crop residue to sell to the compost plant. About 40 local households and 5 dairy farms participated in the initiative and sold their for the worms to thrive. The ideal moisturecontent range for beddings is 45-60\% (Rynk 1992). We used a moisture meter to determine the condition of the beds. We tried to maintain the necessary moisture by spraying water into the beds. Vermiwash is a liquid bio-fertilizer collected after the passage of water through a column of worms. It is a good foliar spray that acts as a plant tonic and helps to reduce plant diseases (Zambare 2008). We made adequate drainage facilities and collection points for taking vermi-wash.

pH Control

Worms don't like too much acidic or alkaline food. They like food that has a $\mathrm{pH}$ value of 6.5-7.5 which is neither acidic nor alkaline in nature. If the feed is a fresh vegetable or fruit 
waste then the $\mathrm{pH}$ value will be in the range of 3.2-3.5. Powdered limestone $\left(\mathrm{CaCO}_{3}\right)$ can be used to improve $\mathrm{pH}$ level as ion acts as the acidity source. As cow dung has an average $\mathrm{pH}$ range of 7.5-8.3 (Yadav 2013) we did not use any limestone. We used 15\% mix of the dry stalks and stems to improve the feed quality.

\section{Stocking Earthworms}

Among thousands of species of earthworms, only a few were used on a wide scale and researched adequately for use in organic waste processing. The species used most commonly include Eisenia foetida (Red wiggler), Lumbricus rubellus (Red worm), Eisenia Andrei (Red tiger), Perionyx excavatus (Blue worm), Eudrilus eugeniae (African night crawler), Dendrobaena veneta and Perionyx hawayana (web-3). We used Eisenia foetida (Red wiggler) worms as their growth and reproduction rate are high. Their breeding cycle is approximately 30 days from mating to laying eggs and the worm population can be double after every 60 days. Red Wigglers are tough and hardy and they are very tolerant of variations in growing conditions. Each day they can consume organic materials equivalent to their body weight to produce nitrogen, phosphorous and potassium-rich castings equal to $75 \%$ of their body weight (Web-4). We collected 0.1 million Red worms (1.5 BDT/worm) from another worm farm and stocked them in Doulatpur compost plant for waste processing and hatching.

\section{Process Monitoring}

The simple smell test is enough for monitoring the process. If the feed smells rotten and wet it's probably turning anaerobic and that's bad. Some call it protein poisoning (web-5). This is when worms start to crawl on the surface, writhe in pain, deform and eventually die. If we see the worms are trying to escape even if they have plenty of food and clean beddings then we have to turn the beddings to get air into the feed. Bad bacteria do not like fresh air but the worms love it. We can use dry paper wastes and newspapers into the feed. We can also change the feed completely and treat it with powdered limestone.

\section{Hatching and production}

We used 10 dedicated beds for hatching the earthworms and filled each bed with $500 \mathrm{~kg}$ of cow dung. The cow dung used was not fresh and used after 3 weeks from the collection time. It helped to reduce the moisture content of the wet dung and decomposition. We put approximately 10,000 numbers of worms in each bed and monitored the worm growth rate and fertilizer production. We used natural condition and native technology and did not use any cooling fan or air conditioner to maintain the indoor environment.

\section{RESULTS}

We started the hatching process in June 2013 and continued it for one full year. We completed three consecutive cycles of 120 days each. We counted output quantity and worm population. We used the net (filters) to segregate worms from the compost output and used them for the next cycle of production and hatching.

In the first cycle, we got 0.15 million worms. After second cycle we got 0.25 million worms, finally, after the third cycle, we got worm population 0.4 million (Fig. 3).After the first cycle, the plant production was $2 \mathrm{MT}$ output fertilizer. After second cycle the plant output 
was 4 MT output fertilizers and finally, at third cycle, we got 10 MT output fertilizers (Fig. 4). analysis in the lab. The test report says, the output fertilizer has a $\mathrm{pH}$ level 7.69 and has

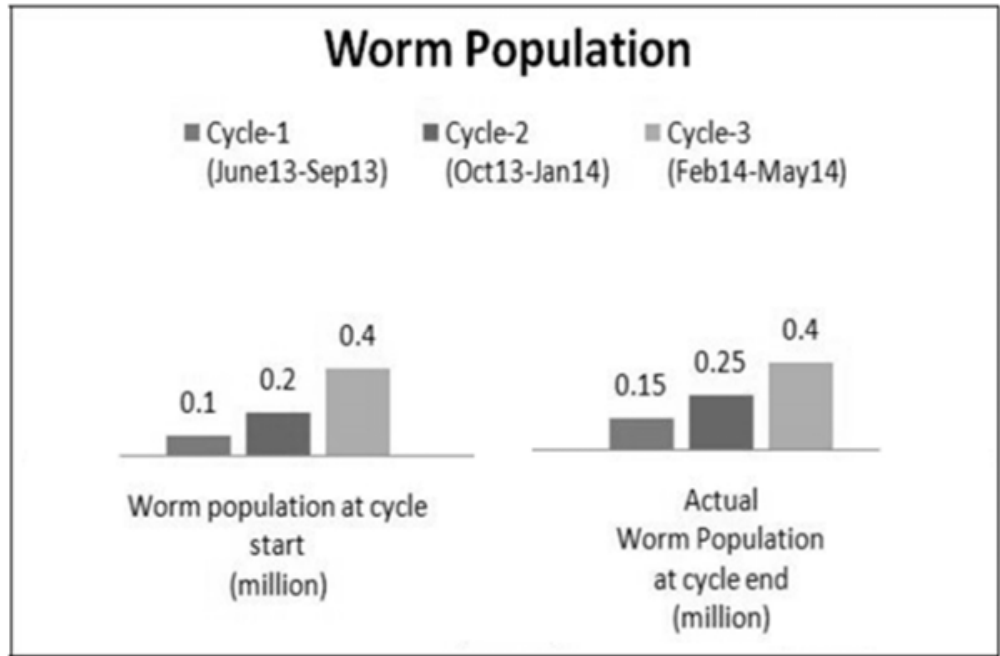

Fig. 3.Worm population in three cycles (One year)

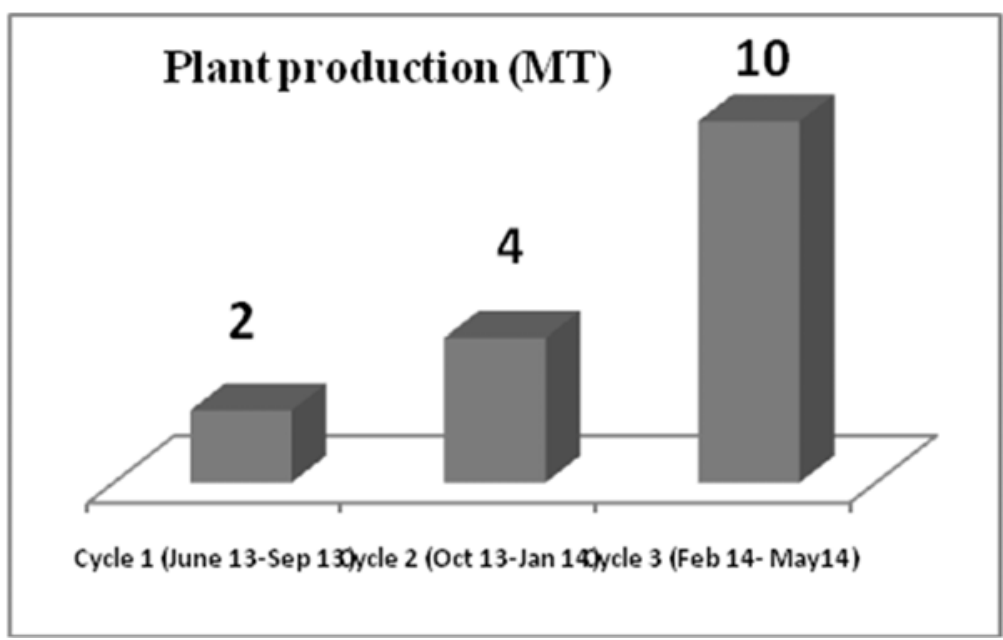

Fig. 4. Plant production in three cycles (One Year)

At this time the factory achieved 3MT/month fertilizer production capacity.

Nutrient content of the compost output

The output fertilizer sample was sent to Department of Soil Science at Mymensingh Agricultural University for the nutrient their laboratory nutrient content as shown in (Table 1).

\section{Cost-Benefit analysis}

A vermicompost plant which can produce 3MT-5MT output fertilizer per month and feed 1 million earthworms requires a 
Table 1. Nutrient content in the output fertilizer sample

\begin{tabular}{ccc}
\hline SL & \multicolumn{3}{c}{ Nutrient in Output } \\
\cline { 2 - 3 } & Content & $(\%)$ \\
\hline 1 & N (Nitrogen) & 1.792 \\
2 & $\mathrm{P}$ (Phosphorous) & 0.5217 \\
3 & $\mathrm{~K}$ (Potassium) & 1.514 \\
4 & $\mathrm{~S}$ (Sulphur) & 0.135 \\
5 & $\mathrm{Na}$ (Sodium) & 3.5642 \\
6 & Zinc (Zn) & 0.0147 \\
7 & Fe (Iron) & 0.33092 \\
8 & $\mathrm{Mn}$ (Manganize) & 0.00933 \\
9 & $\mathrm{~B}$ (Boron) & 0.00688 \\
10 & $\mathrm{Mg}$ (magnesium) & 0.48 \\
11 & $\mathrm{Ca}$ (Calcium) & 5.5 \\
12 & $\mathrm{Cu}$ (Cupper) & 0.00307 \\
\hline
\end{tabular}

minimum land area of 15,000 to 18000 square feet. It costs around 1.5 Lac BDT in rural areas. The plant construction requires around 1.5 Lac BDT. If the plant starts with 0.1 million worms, the cost will be $1.5 \mathrm{Lac}$ BDT (considering 1.5 BDT/worm). In that case total capital investment would be: Land cost + Plant set up cost + Worm Procurement cost $=1.5+1.5+1.5=4.5$ Lac BDT. Plant Operation costs include raw material procurement cost (1 $\mathrm{BDT} / \mathrm{Kg})$, labor cost (0.5 BDT/Kg) and packaging marketing cost $(0.5 \mathrm{BDT} / \mathrm{Kg})$. In total, the production cost is $2 \mathrm{BDT} / \mathrm{kg}$. At present Vermicompost fertilizer is sold in the market at a wholesale price of $12 \mathrm{BDT} / \mathrm{Kg}$ and a retail price 15 $\mathrm{BDT} / \mathrm{kg}$. Considering the wholesale price, there is a profit margin of $12-2=10 \mathrm{BDT} / \mathrm{kg}$. If the factory can produce a sustainable output of 3 MT per month the simple payback period would be 15 months. If proper effort is there, within 2-3 years the factory can successfully pay off to its investors. However continuous supply of raw material (any biomass or animal waste) is very critical for the sustainability of the plant. Entrepreneurs should give extra focus on this matter prior to the establishment.

\section{DISCUSSION}

From Table 2, we get reference value of nutrient content (web-6) and we compare it with the test results of Table- 1 . We found Nitrogen content $1.792 \%$ is slightly above the usual range of $0.51-1.6 \%$. The phosphorus content $0.5217 \%$ is within the reference range of $0.19-1.02 \%$. The sodium content $3.5642 \%$ is higher than the average range of $0.058-0.158 \%$. In this way, we compared the other elements of the fertilizer and found that the output fertilizer is effective for the agricultural, horticultural, and ornamental and vegetables at any stage of the crop.

Though vermicompost fertilizer has several economic and environmental advantages, Times of India (web-7) reported that the demand for vermicompost has decreased 
Table 2. Reference Nutrient element ratio for vermin compost fertilizer

\begin{tabular}{lll}
\hline Nuirient Dement & Vermicompost (\%) & Garden Compost (\%) \\
\hline Organic carbon & $9.8-13.4$ & 12.2 \\
Nitrogen & $0.51-1.61$ & 0.8 \\
Phosphorus & $0.19-1.02$ & 0.35 \\
Potassium & $0.15-0.73$ & 0.48 \\
Calcium & $1.18-7.61$ & 2.24 \\
Magnesium & $0.093-0.568$ & 0.57 \\
Sodium & $0.058-0.158$ & $<0.01$ \\
Zinc & $0.0042-0.110$ & 0.0012 \\
Copper & $0.0025-0.0048$ & 0.0017 \\
Iron & $0.2050-1.3313$ & 1.169 \\
Manganese & $0.0105-0.2038$ & 0.0414 \\
\hline
\end{tabular}

over the years and only rich farmers, who export the farm production, are interested in buying the compost while no small farmers want to invest in it. They prefer chemical fertilizers over vermicompost. Though the price of vermicompost is low and it gives quality agricultural products, the quantity of production is very low compared to the chemical fertilizer production. Another criticism is that organic fertilizer works slowly on soil and its productive efficiency is lower than chemical fertilizer, which is costly (web-8). Very few companies produce organic fertilizer and some of its quality is questionable. The government provides a higher subsidy for the chemical fertilizer that makes more vested interests so that disparity exists regarding the political economy of fertilizer policy and promotion.

\section{CONCLUSION}

In the present agricultural system, energy crisis, food shortage and environmental pollution are the main hurdles facing the people of Bangladesh. Over-dependence on chemical fertilizers and pesticides and nonjudicious use of synthetic agrochemicals are posing a serious threat to ecological balance. Maintenance of healthy soil has now become a challenge for crop cultivation. The relatively high success of organic recycling in some countries is due to the high awareness and growing concern on the ill effects of chemical farming on the environment. The enormous amount of organic wastes available for recycling should be explored for possible bioconversion to utilize the embedded nutrients of the wastes for sustainable soil health and crop growth. Vermicomposting has gained the popularity for the recycling of organic wastes in Bangladesh. It will not only help to meet the deficit of fertilizer nutrients but also to conserve energy, minimize pollution, save foreign exchange and improve the fertilizer use efficiency. Recent scientific advancement need to be exploited for more effective, economical and sustainable recycling of diverse organic wastes. 


\section{ACKNOWLEDGEMENT}

We would like to thank Dr. Saiful Huque for his help to complete this paper. We also acknowledge the support from Carbon Emission Reduction \& Livelihood (CERL), Bhola, Bangladesh.

\section{REFERENCE}

Blatt, C.R. 1991. Comparison of several organic amendments with a chemical fertilizer for vegetable production. Scientia Horticulturae 47: 177-191

Clark, M.S., W.R. Horwath, C. Shennan and K.M. Scow. 1998. Changes in soil chemical properties resulting from organic and lowinput farming practices. Agronomy Journal 90: $662-671$.

Karungi, S.2006. Effects of organic versus conventional fertilizers on insect pests, natural enemies and yield of Phaseolus vulgaris. Agriculture, Ecosystems and Environment 115:51-55.

Olfati, J.A., G.H. Peyvast, Z. Nosrati-Rad, F. Saliqedar and F. Rezaie. 2009. Application of municipal solid waste compost on lettuce yield. International Journal of Vegetable Science 15(2): 168-172.

Peterson, S.O., K. Henriksen, G.K. Mortensen, P.H. Krogh, K.K. Brandt, J. Sorensen, T. Madsen, J. Petersen and C. Gron. 2003. Recycling of sewage sludge and household compost to arable land: fate and effects of organic contaminants, and impact on soil fertility. Soil \& Tillage Research 72: 139-152.

Peyvast, G.H., M. Sedghiand J.A. Olfati. 2007. Effect of municipal solid waste compost on weed control, yield and some quality indices of green pepper (Capsicum annuum L.). Biosciences: Biotechnology Research Asia 4(2): 449-456.

Rynk, R. 1992. On-Farm Composting Handbook, Natural Resource, Agriculture, and Engineering Service (NRAES-54), Ithaca, NY.

Shimbo, S. 2001. Cadmium and lead contents in rice and other cereal products in Japan in
1998-2000. Science of the Total Environment 281: 165-175.

Smil, V. 2001.Enriching the Earth: Fritz Haber, Carl Bosch, and the Transformation of World Food Production. Cambridge, USA: The MIT Press.

Tandon, H.L.S. 1995. Recycling of crop, animal, human and industrial wastes in agriculture. Technical Bulletin. Fertilizer Development and Consultation Organization, New Delhi, India. pp. 55.

Toor, R.K., G.P. Savage and A. Heeb. 2006. Influence of different types of fertilizers on the major antioxidant components of tomatoes. Journal of Food Composition and Analysis 19: 20-27.

Yadav, A., R. Gupta and K.G. Vinod. 2013. Organic manure production from cow dung andbiogas plant slurry by vermicomposting underfield conditions. International Journal of Recycling of Organic Waste in Agriculture 2: 1-7.

Zambare, V.P., M.V. Padul, A.A. Yadavand T. Shete. 2008. Vermiwash: biochemical and microbiological approach as Ecofriendly soil conditioner. ARPN Journal of Agricultural and Biological Science 3(2): 112-119

\section{WEBSITE LINKS}

1. https://www.scribd.com/doc/47505555/ Manual-of-On-Farm-Vermicomposting

2. https://en.climate-data.org/location/57276/

3. http://www.cropsreview.com/night-crawler. $\mathrm{html}$

4. http://www.wormfarmfacts.com/Red-Worms. html

5. http://www.wormman.com/ph_of_your_soil_ and_worm_bed.com

6. http://www.researchgate.net/figure/2818632191 tbl1_Table-142-Nutrient-Composition of$\overline{\text { Vermicompost-and-Garden-Compost }}$

7. http://timesofindia.indiatimes.com/city/ nagshik/Farmers-gojj-for-chemicals-insteadof-vermicompost/articleshow/19487429.cms

8. https://practicalaction.org/blog/where-we work/ bangladesh/promoting-organic-fertilizer -in-bangladesh-challenges-and-prospects/

(Received revised manuscript on 27 March, 2018) 